\title{
Diagnosis of HIV-related malignancies in resource-constrained settings of sub-Saharan Africa, a cautionary tale for non-Hodgkin's lymphoma
}

Leona W Ayers ${ }^{1,3,4^{*}}$, Robert Lukande ${ }^{2,3}$, Lynnette K Tumwine 2,4

From $12^{\text {th }}$ International Conference on Malignancies in AIDS and Other Acquired Immunodeficiencies (ICMAOI)

Bethesda, MD, USA. 26-27 April, 2010

\section{Background}

Non-Hodgkin's lymphoma (NHL) subgroups, immunophenotypes, and genotypes have been defined in developed countries but how that information translates to resource-constrained sub-Saharan Africa medical settings is undocumented. Local published data on NHL subgroups come largely from retrospective clinical biopsy study sets of paraffin-embedded tissues filed in local pathology archives. Relatively poorer representation of the rural and low socioeconomic populations is likely in such data. Prospectively identified NHL subgroups using immunologic and molecular techniques in consecutive presentations of patients would best clarify NHL subgroups and confounding diagnoses.

\section{Materials and methods}

Approximately 456 cases of malignant lymphoma (ML) from both the sub-Saharan African Lymphoma Consortium and Mid-region AIDS and Cancer Specimen Resource (ACSR) projects in East Africa were examined for microscopic morphology and 30 monoclonal antibodies for common NHL antigens; Lana-1 for HHV-8 (immunohistochemical, IHC); in situ hybridization (ISH) for EBV-encoded RNA, kappa/lambda light chains

Table 1 Confounding tumor look-alikes

\begin{tabular}{lll}
\hline Tumor & Subtype examples/confounding factors & Presentation or clinical classification \\
\hline Fungal infections & African histoplasmosis & Kaposi's sarcoma \\
\hline \multirow{4}{*}{ Viral lymphadenopathy } & Entomophthoromycosis - Basidiobolus ranarum & $\mathrm{NHL}$ \\
& HIV-1 lymphadenopathy, follicular hyperplasia & $\mathrm{NHL}$ \\
\cline { 2 - 3 } & EBV lymphadenopathy or lymphoproliferative disorders & $\mathrm{NHL}$ \\
& HHV-8 lymphoblastic lymphoma & Burkitt lymphoma \\
& Castleman's disease & Atypical hyperplasia \\
\hline \multirow{3}{*}{ Pediatric small round cell tumors } & Undifferentiated neuroblastoma & Burkitt lymphoma \\
\hline Carcinomas & Primitive neuroectodermal tumors (PNET) & Burkitt lymphoma \\
\hline & Lymphocyte predominant & Burkitt lymphoma \\
\hline
\end{tabular}

\footnotetext{
*Correspondence: ayers.1@osu.edu
}

'Department of Pathology, The Ohio State University, Columbus, OH, USA

Full list of author information is available at the end of the article 
(Ventana, Tucson, AZ); and fluorescent in situ hybridization (FISH) c-myc $\mathrm{t}(8 ; 14)$ (Abbott/Vysis, Downer's Grove, IL).

\section{Results}

There was a small but consistent population of other tumors that reduced the accuracy of both the clinical and histopathology diagnosis of NHLs including those given in Table 1.

\section{Conclusions}

Clinical diagnosis of NHL is complicated by other pathological entities that lead to inaccuracies. Histopathology diagnosis based on hematoxylin and eosin (H\&E) stained tissue morphology alone improves accuracy (vs. clinical diagnoses alone) but can provide additional inaccuracies due to tumor look-alikes. Caution is warranted in considering either clinical diagnosis or local histopathology diagnosis in a resource-constrained medical setting as accurate in the conduct of clinical treatment trials or epidemiology studies.

\section{Acknowledgements}

This article has been published as part of Infectious Agents and Cancer Volume 5 Supplement 1, 2010: Proceedings of the $12^{\text {th }}$ International Conference on Malignancies in AIDS and Other Acquired Immunodeficiencies (ICMAOI). The full contents of the supplement are available online at http://www.biomedcentral.com/1750-9378/5?issue=S1.

\section{Author details}

'Department of Pathology, The Ohio State University, Columbus, OH, USA. ${ }^{2}$ Department of Pathology, Makerere University, Kampala, Uganda. ${ }^{3}$ AIDS and Cancer Specimen Resource, ACSR, NIH, USA. ${ }^{4}$ Sub-Saharan Africa Lymphoma Consortium, SSALC, ACSR, OHAM, USA.

Published: 11 October 2010

doi:10.1186/1750-9378-5-S1-A19

Cite this article as: Ayers et al:: Diagnosis of HIV-related malignancies in resource-constrained settings of sub-Saharan Africa, a cautionary tale for non-Hodgkin's lymphoma. Infectious Agents and Cancer 2010 5(Suppl 1):A19.
Submit your next manuscript to BioMed Central and take full advantage of:

- Convenient online submission

- Thorough peer review

- No space constraints or color figure charges

- Immediate publication on acceptance

- Inclusion in PubMed, CAS, Scopus and Google Scholar

- Research which is freely available for redistribution

Submit your manuscript at www.biomedcentral.com/submit 